\title{
Perancangan Dan Realisasi Antena Mikrostrip Monopole Segiempat Pada Frekuensi 546 Mhz Untuk Aplikasi Dvb-T \\ Aprinal Adila Asril ${ }^{1}$, Yustini $^{2}$, Hadria Octavia ${ }^{3}$ \\ 123 Jurusan Teknik Elektro Politeknik Negeri Padang aprina169@gmail.com \\ Kampus Politeknik Negeri Padang, Limau Manis Padang
}

\begin{abstract}
Microstrip antenna is a metal conductor attached above the groundplane which diantarannya there are dielectric materials. Microstrip antenna consists of 3 main parts of patch, substrate and groundplane. A microstrip antenna that can be used in the DVB-T application concept. The DVB-T (Digital Video Broadcasting Terrestrial) system, is a direct broadcasting system from terrestrial transmitters.In this final project is made of microstrip antenna monopole for DVB-T by using double layer PCB and Zeland software. This antenna is designed at a frequency of $546 \mathrm{MHz}$. The material used is PCB epoxy (FR4) double layer with material thickness $1.6 \mathrm{~mm}$ and dielectric constant of $4.7 \mathrm{~mm}$. The microstrip antenna is tested to obtain the resonance frequency, bandwidth, VSWR, HPBW, Gain and polaradiation values which are then compared with simulation results using Zeland Program Manager (IE3D) software. In antenna measurement results obtained results for microstrip antenna such as return loss $=-\mathbf{2 5} \mathrm{dB}$ at frequency $=\mathbf{5 4 5} \mathrm{MHz}$, bandwidth $=140 \mathrm{MHz}$, with value VSWR $=1.48 \mathrm{~dB}, \mathrm{HPBW}=750$ and polaradiasi Bidirectionall.
\end{abstract}

Keywords: Microstrip antenna, resonance frequency, bandwitdh, VSWR, polarization.

Abstrak - Antena mikrostrip adalah suatu konduktor metal yang menempel diatas groundplane yang diantarannya terdapat bahan dielektrik. Antena mikrostrip terdiri atas 3 bagian utama yaitu patch, substrate dan groundplane. Antena mikrostrip yang dapat digunakan dalam konsep aplikasi DVB-T. Sistem DVB-T (Digital Video Broadcasting Terestrial), merupakan sistem penyiaran langsung dari pemancar bumi (terrestrial). Pada penelitian ini dibuat antena mikrostrip monopole untuk DVB-T dengan menggunakan PCB double layer dan software Zeland. Antena ini dirancang pada frekuensi 546 MHz. Bahan yang digunakan adalah PCB epoxy (FR4) double layer dengan ketebalan bahan 1.6 mm dan konstanta dielektrik sebesar $4.7 \mathrm{~mm}$. Antena mikrostrip tersebut diuji untuk mendapatkan nilai frekuensi resonansi, bandwidth, VSWR, HPB W, Gain dan polaradiasi yang kemudian hasilnya dibandingkan dengan hasil simulasi menggunakan software Zeland Program Manager (IE3D). Pada hasil pengukuran antena diperoleh hasil untuk antena mikrostrip diantaranya nilai return loss = -25 dB pada frekuensi $=545 \mathrm{MHz}$, bandwidth $=140 \mathrm{MHz}$, dengan nilai VSWR $=1.48 \mathrm{~dB}, \mathrm{HPBW}=750 \mathrm{dan}$ polaradiasi berbentuk Bidirectional.

Kata kunci: Antena mikrostrip, frekuensi resonansi, bandwitdh, VSWR, polaradiasi.

\section{PENDAHULUAN}

Migrasi dari sistem penyiaran analog ke digital menjadi tuntutan teknologi secara internasional. Aplikasi teknologi digital pada sistem penyiaran televisi mulai dikembangkan di pertengahan 1990-an. Uji coba penyiaran televisi digital dilakukan pada tahun 2000 dengan pengoperasian sistem digital dilakukan bersamaan dengan siaran analog sebagai masa transisi.

Dirjen Postel memilih standard penyiaran digital eropa yaitu DVB-T. Selama migrasi, Dirjen Postel perlu mematangkan persiapan di sisi regulasi, stasiun televise perlu menyiapkan di sisi alat transmisi,dan masyarakat perlu bersiap diri di sisi alat penerima. Di wilayah Sumatera barat terkhususnya kota padang untuk DVB-T yang telah dipancarkan yakni LPP TVRI Sumatera Barat dengan frekuensi $546 \mathrm{Mhz}$. Sistem DVB-T, merupakan sistem penyiaran

langsung dari pemancar bumi (teresstrial) ke pengguna.

DVB-T lebih di kenal dengan siaran televisi digital dan menjadi standar yang umum di gunakan di dunia dan juga tengah di adaptasi di Indonesia karena memiliki beberapa kelebihannya, terutama karena kehandalan DVB-T yang mampu mengirimkan sejumlah besar data pada kecepatan tinggi secara point-to-multipoint.[6]

\section{1 . Perancangan}

\section{METODE}

\subsubsection{Tujuan Perancangan dan Pembuatan}

Dalam perancangan dan pembuatan antena ini bertujuan untuk mendapatkan hasil kerja yang 
baik berdasarkan fungsi yang diinginkan, maka perancangan dan antena ini harus di lakukan dengan teliti dan cermat, agar mempermudahkan dan membantu antenna mikrostrip ini.

\subsubsection{Diagram Alir Perancangan Antena}

Sebelum merancang antena dengan IE3D, perlu ditentukan parameter-parameter apa saja karakteristik antena yang sesuai untuk DVB-T, diantaranya dapat dilihat pada tabel 1 berikut :[6]

\begin{tabular}{ll} 
Frekuensi Kerja $(\mathrm{MHz})$ & $542-550$ \\
\hline Frekuensi Tengah $(\mathrm{MHz})$ & 546 \\
\hline Return Loss $(\mathrm{dB})$ & $<-10$ \\
\hline Bandwidth $(\mathrm{MHz})$ & 140 \\
\hline VSWR & $\leq 2$ \\
\hline Impedansi $(\Omega)$ & 50 \\
\hline Gain $(\mathrm{dB})$ & $\geq 3$ \\
\hline Pola Radiasi & Bidirectional
\end{tabular}

Dalam perancangan dan pembuatan antena ini melalui beberapa tahapan serta metode yang digunakan yang disusun dalam bentuk diagram alir seperti yang terlihat pada gambar 1 berikut ini :

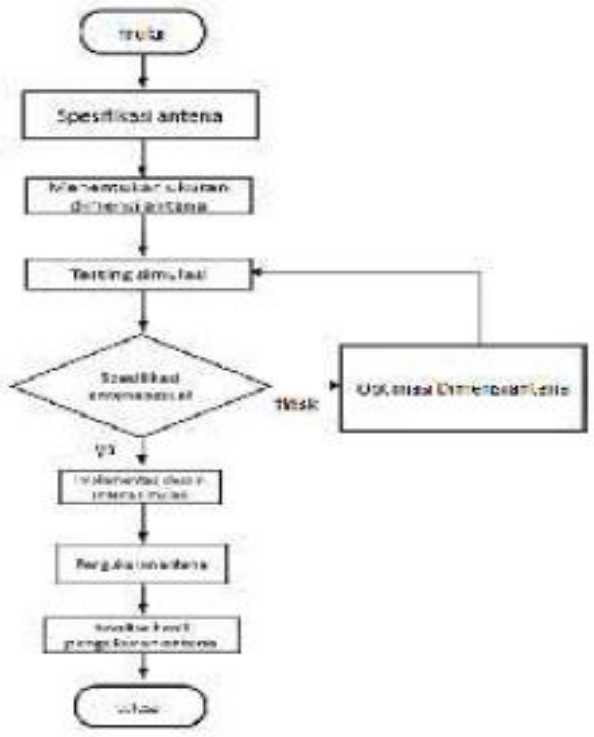

Gambar 1. Flowchart Perancangan dan Pembuatan Antena

\subsection{Ukuran Antena}

\subsubsection{Perancangan Ukuran Antena Dengan Teori Perhitungan}

Perancangan antena mikrostrip monopole segi empat dimulai dengan menentukan perhitungan panjang dan lebar dari patch, ground plane, saluran pencatu untuk antena mikrostrip serta jarak antara patch. Setelah didapatkan ukuran yang didapatkan dari perhitungan barulah dilakukan simulasi dengan menggunakan simulator IE3D.[5]

Tahapan yang dilakukan dalam perancangan antena mikrostrip adalah sebagai berikut :

1. Menentukan Karakteristik Antena

Pada rancangan ini diharapkan antena dapat bekerja pada frekuensi $546 \mathrm{MHz}$. Pada rentangan frekuensi tersebut diharapkan antena memiliki parameter VSWR $\leq 2$, return loss $\leq$ $10 \mathrm{~dB}$ dan impedansi sebesar $50 \Omega$.

2. Penentuan Jenis Subtract

Jenis subtract yang digunakan dalam perancangan ini adalah PCB (Printed Circuit Boar) dengan kode FR4-Epoxy yang memiliki ketebalan subtract $1,6 \mathrm{~mm}$ dan konstanta dielektrik 4,7. Jenis subtract ini dipilih selain harganya terjangkau, subtract jenis ini juga banyak diproduksi dan memiliki kualitas yang cukup baik.

3. Perhitungan Dimensi Patch

a. Lebar Patch (Wp)

$$
\begin{aligned}
& W p= \frac{c}{2 F o \sqrt{\frac{\delta r+1}{2}}} \\
&= \frac{3 \times 10^{8}}{2 \times 0.54 \times 10^{9} \times \sqrt{\frac{4.7+1}{2}}} \\
&=\frac{3 \times 10^{8}}{1.8432 \times 10^{9}} \\
& 0,1627 \mathrm{~m}=16.27 \mathrm{~mm}
\end{aligned}
$$

b. Panjang Patch (Lp)

$$
\begin{aligned}
& \text { Ereff } \\
& =\frac{\varepsilon r+1}{2}+\varepsilon \frac{\varepsilon r-1}{2}\left(\frac{1}{\sqrt{1+\left(\frac{12 h}{W p}\right)}}\right) \\
& =\frac{47+1}{2}+\left(\frac{4.7-1}{2}\left(\frac{1}{\sqrt{1+\left(\frac{12 \times 1.6}{1}\right)}}\right)\right) \\
& =2.85+(1,85 x 0,6) \\
& =2.8+1,25 \\
& =4.1 \mathrm{~mm}
\end{aligned}
$$




$$
\begin{aligned}
& \text { Lreff }=\frac{C}{2 x F o \sqrt{\varepsilon r e f f}} \\
& =\frac{3 \times 10^{8}}{2 \times 0.546 \times 10^{9} \times \sqrt{4} 4.1} \\
& =\frac{3 \times 10^{8}}{2.21 \times 10^{9}} \\
& =1.3 \times 10^{-1} \mathrm{~m}=13 \mathrm{~mm} \\
& =0.41 h\left(\frac{\left(E_{\text {reff }}+0.3\right)\left(\left(\frac{W p}{h}\right)+0.264\right)}{\left(E_{\text {reff }}-0.0258\right)\left(\left(\frac{W_{p}}{h}\right)+0.8\right)}\right) \\
& =0.416 \times 1.6\left(\frac{(4.34+0.3)\left(\left(\frac{16.27}{1.6}\right)+0.264\right)}{(4.34-0.0258)\left(\left(\frac{16.27}{1.6}\right)+0.8\right)}\right) \\
& =0.66 \times\left(\frac{45.8656}{41.648}\right) \\
& =0.66 \times 1.10 \\
& =0.726 \mathrm{~mm} \\
& L=\text { Leff }-2 \Delta L \\
& =13-(2 \times 0.69) \\
& =13-1.453=11.547 \mathrm{~mm}
\end{aligned}
$$

4. Perhitungan Dimensi Ground Plane

a. Lebar Ground Plane

$$
\begin{aligned}
W g & =6 h+W p \\
& =(6 \times 1.6)+16.27 \\
& =9.6+16.27 \\
& =25.87 \mathrm{rum}
\end{aligned}
$$

b. Panjang Ground Plane

$$
\begin{aligned}
L g & =6 h+L \\
& =(6 \times 1.6)+28.54 \\
& =9.6+28.54 \\
& =38.14 \mathrm{~mm}
\end{aligned}
$$

5. Perhitungan Saluran Pencatu Mikrostrip a. Lebar Saluran

$$
\begin{aligned}
B \quad & =\frac{60 \pi \pi^{2}}{Z 0 \sqrt{\varepsilon r}} \\
& =\frac{60 x\left(3.14^{2}\right)}{50 \sqrt{4.7}} \\
& =\frac{591.51}{108.39} \\
& =5.45 \mathrm{~mm}
\end{aligned}
$$

$$
\begin{aligned}
& W s=\frac{2 h}{\pi}(B-1-\ln (2 B-1) \\
& +\left(\frac{s r-1}{2 \varepsilon r}\right)[\ln (B-1) \\
& \left.+0.39-\left(\frac{0.61}{4.7}\right)\right] \\
& =\frac{2 \times 1.6}{3.14} \times(5.45-1 \\
& -\operatorname{in}(2 \times 5.45) \\
& +\left(\frac{4.7-1}{2 \times 4.7}\right)[\ln (5.45-1)+0.39 \\
& -\left(\frac{0.51}{4.7}\right. \\
& =1.20 \times(5.45-1-2.29 \\
& +0.39(1.49 \\
& +0.39-0.13 \text { ) } \\
& =1.02 \mathrm{x}(2.16+0.68) \\
& =1.02 \times 2.84 \\
& =2.89 \mathrm{~mm}
\end{aligned}
$$

b. Panjang Saluran

$$
\begin{aligned}
& =\frac{\varepsilon r+1}{2}+\left(\frac{\varepsilon r-1}{2}\left(\frac{1}{\sqrt{1+\left(\frac{12 h}{W s}\right)}}\right)\right. \\
& =\frac{4.7+1}{2}+\left(\frac{4.7-1}{2}\left(\frac{1}{\sqrt{1+\left(\frac{12 \times 1.5}{2.89}\right)}}\right)\right) \\
& =2.85+(1.85 \times 0.36) \\
& =2.8+0.66 \\
& =3.51 \mathrm{rmm} \\
& \lambda_{0}=\frac{c}{f} \\
& =\frac{3 \times 10^{8}}{0.546 \times 10^{5}} \\
& =0.5495 \mathrm{~m} \\
& =549 \mathrm{~mm} \\
& \Delta L=\frac{\lambda_{0}}{\sqrt{\varepsilon_{r e f f}}} \\
& =\frac{549}{\sqrt{3.51}} \\
& =293.11 \mathrm{rWr} \\
& \text { Ls }=\underline{\Delta L} \\
& =\frac{293.11}{2}
\end{aligned}
$$

Maka didapatkan dimensi antena berdasarkan perhitungan yang telah dilakukan adalah sebagai berikut :

Tabel 2 Ukuran Dimensi Antena Sesuai

\begin{tabular}{rlll}
\hline Dimensi & Patch & $\begin{array}{c}\text { Ground } \\
\text { Plane }\end{array}$ & saluran \\
\hline Lebar $(\mathrm{mm})$ & 16,27 & 25,87 & 2,89 \\
\hline Panjang $(\mathrm{mm})$ & 11,547 & 38,14 & 146,55 \\
\hline
\end{tabular}


Berikut hasil antena sesuai dengan teori :

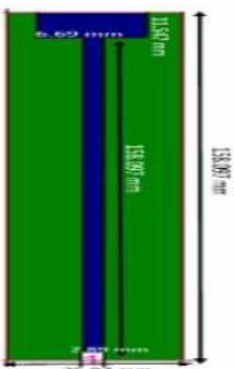

Gambar 2. Hasil Simulasi Antena Sesuai

Gambar 3 adalah hasil simulasi dari antena sesuai perhitungan.

Berdasarkan hasil simulasi pada gambar 7 belum didapatkan parameter yang sesuai untuk aplikasi $D V B-T$. Dimana dari hasil simulasi tersebut didapatkan frekuensi kerja yang besar $3 \mathrm{MHz}$ dengan return loss sudah dibawah $-10 \mathrm{~dB}$. Nilai tersebut tidak termasuk criteria antena maka dari itu dilakukan proses optimasi untuk menghasilkan antena yang sesuai dengan spesifikasi untuk aplikasi $D V B-T$.

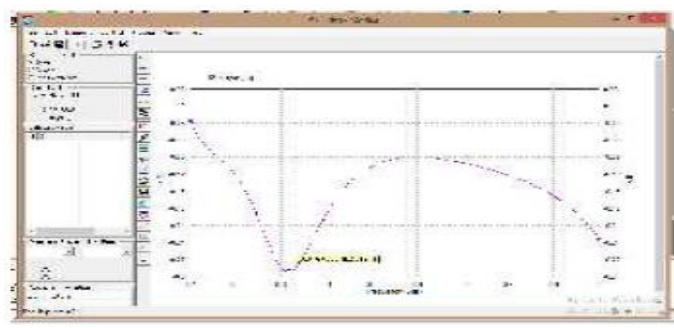

Gambar 3. Hasil Simulasi Antena Sesuai Perhitungan

\subsubsection{Optimasi Desain Antena}

Optimasi desain antena adalah melakukan pergeseran dengan menambah atau mengurangi dimensi antena pada patch, ground plane, dan saluran pencatu. Untuk mendapatkan desain yang memenuhi syarat jadi banyak design optimasi yang telah dicoba. Berikut ini merupakan beberapa optimasi yang telah dilakukan diantaranya:

\section{Optimasi Pertama}

Pada optimasi pertama penambahan ukuran groundplane dimensinya sehingga menjadi groundplane penuh dan serta penambahan dimensi panjang patch dan dimensi lebar patch. Ukuran dimensi antena hasil optimasi pertama ditunjukkan oleh gambar 4.

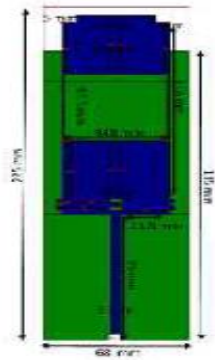

Gambar 4. Desain Antena Optimasi Pertama

Berdasarkan hasil optimasi pertama didapatkan nilai frekuensi kerja $390 \mathrm{MHz}$ dengan return loss besar dari $-10 \mathrm{~dB}$ hingga mencapai -12 dB. Maka dari itu dilakukan optimasi antena untuk mendapatkan parameter antena sesuai dengan spesifikasi yang diinginkan. Hasil simulasi dari optimasi pertama ditunjukkan oleh gambar 5 dibawah ini.

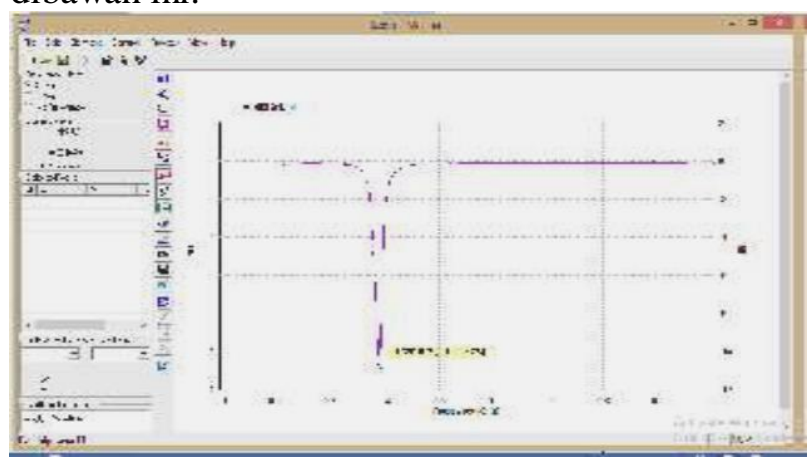

Gambar 5. Hasil Simulasi Optimasi Pertama

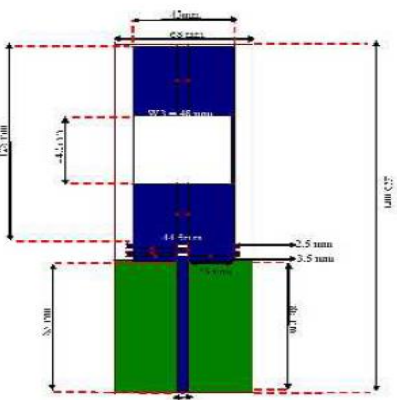

Gambar 6. Desain Antena Optimasi Kedua

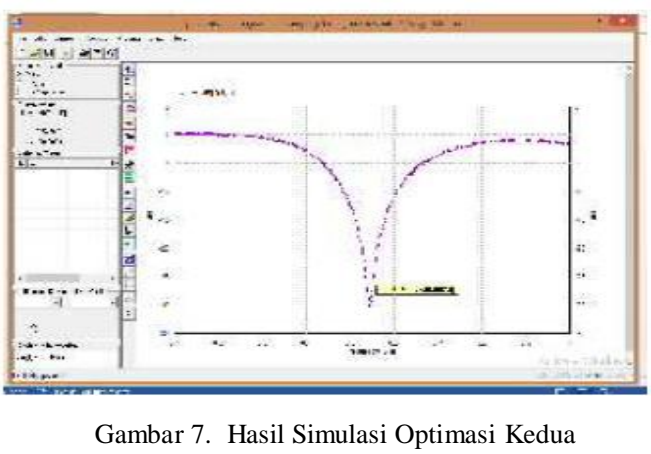


Berdasarkan hasil simulasi diatas didapatkan nilai return loss sebesar $-30.0023 \mathrm{~dB}$ dengan frekuensi kerja $545 \mathrm{MHz}$. Hasil simulasi dari optimasi ke dua merupakan hasil terbaik karena hasilnya telah sesuai dengan spesifikasi dari antena untuk aplikasi $D V B-T$.

\subsubsection{Pembuatan Antena Mikrostrip Monopole} Segi Empat [3]

Langkah-langkah dalam pembuatan antena mikrostrip monopole segi empat adalah sebagai berikut :

1. Mempersiapkan semua bahan dan peralatan yang akan digunakan.

2. Memotong PCB double layer sesuai dengan ukuran groundplane yaitu 22.5 x $6.8 \mathrm{~cm}$, kemudian bersihkan PCB dengan amplas.

3. Membuat desain yang ada di software ke papan PCB sesuai dengan ukuran aslinya.

4. Menutup desain menggunakan striker, termasuk bagian groundplane-nya.

5. Kemudian menyiapkan larutan Ferriclorida $(\mathrm{FeCl} 3) 1$ bungkus dan air panas 1 gelas dalam wadah yang berukuran lebih besar dari ukuran PCB.

6. Memasukan PCB ke dalam larutan Ferriclorida $(\mathrm{FeCl} 3)$, tunggu hingga kira-kira 3 - 4 menit.

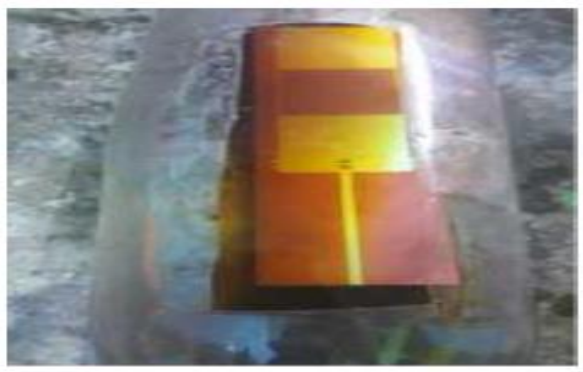

Gambar 8. Proses Pelarutan

Setelah proses pelarutan selesai, kemudian dilakukan pembersihan pada PCB dengan air, setelah itu dikeringkan barulah di amplas, tujuannya supaya nanti ketika penyolderan timah yang akan disolder melekat ke papan PCB yang telah dilarutkan tersebut. Seperti gambar 9.

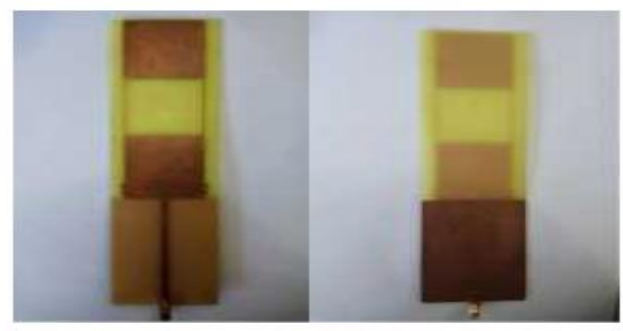

Gambar 9. Antena yang Sudah Diberi Port

\subsection{REFERENSI}

\subsubsection{Antena Microstrip}

Antena mikrostrip adalah antena yang terdiri dari atas elemen radiasi (konduktor) yang sangat tipis yang diletakkan dibidang pertanahan (ground plane), dimana antara bidang tersebut dengan elemen radiasi (konduktor) dipisahkan oleh substrat dielektrik dengan nilai konstanta dielektrik (Er) tertentu.[2]

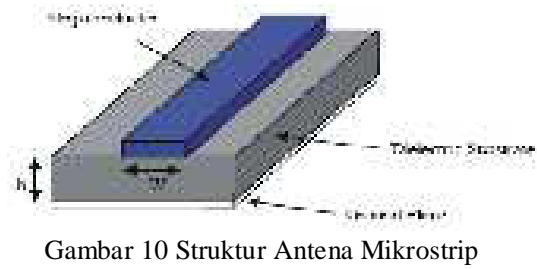

Nilai konstanta dielektrik suatu PCB berkisar antara $2.2 \leq \varepsilon \mathrm{r} \leq 12$. Untuk performance antena pemilihan substrate sangat berpengaruh, semakin tebal substrate maka permitifitasnya semakin kecil sehingga bandwidth juga semakin lebar tetapi dimensi akan bertambah besar begitu juga sebaliknya. Antena mikrostrip mempunyai nilai radiasi yang paling kuat terutama pada daerah pinggiran di antara tepi strip conductor (patch). Oleh sebab itu, kejelian dalam menetapkan spesifikasi, ukuran, dan performa akan menghasilkan antena mikrostrip yang mempunyai ukuran yang kompak dengan performa masih dalam toleransi. Bentuk konduktor bisa bermacam-macam tetapi yang pada umumnya digunakan berbentuk empat persegi panjang dan lingkaran karena bisa lebih mudah dianalisis. Adapun jenis-jenis antena mikrostrip terlihat pada gambar 11 [2]

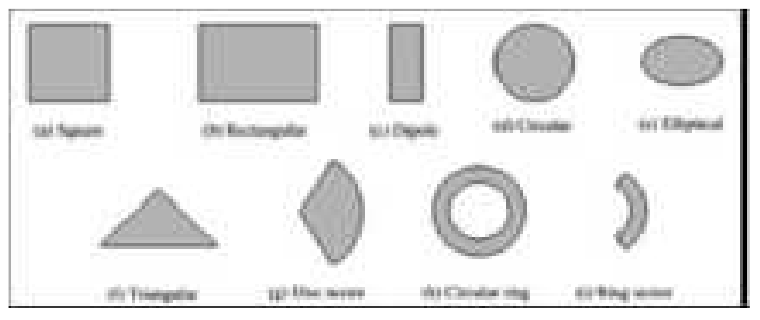

Gambar 11.Jenis-jenis Antena Mikrostrip.

\subsubsection{Parameter-parameter Dasar Antena}

Penilaian kecocokan antena untuk digunakan sesuai dengan kebutuhannya dapat dilakukan dengan melihat parameter-parameter dasar. Beberapa dari parameter tersebut saling berhubungan satu sama lain. 
Parameter-parameter antena yang biasanya digunakan untuk menganalisis suatu antena adalah pola radiasi, polarisasi, impedansi masukan, bandwidth, Voltage Standing Wave Ratio (VSWR), Half Power Beam Width (HPBW), Front to Back Ratio (FBR), return loss, dan gain.[4]

\section{a. Pola Radiasi Antena}

Sama halnya dengan melihat cahaya lampu jalan yang membentuk pola tertentu. Begitu juga dengan antenna akan membentuk pola pancar energi tertentu yang disebut pola radiasi. Pola radiasi menggambarkan distribusi dan pancaran sinyal suatu antena dalam fungsi sudut.

Pola radiasi antena dapat dilihat dilihat pada sistem koordinat tiga dimensi dan dalam koordinat polar (sudut). Secara Umum pola radiasi terdiri dari Main Lobe atau Main Beam pada daerah tegak lurus terhadap antenna (00) yang menunjukkan arah pancaran atau arah penerimaan maksimum dari antena. Dan Minor Lobe adalah Lob lain selain Main Lobe. Lebar sorotan dari antena disebut dengan Beam widht atau Half Power Beam Widht (HPBW), ini sama dengan lebar sudut pada setengah daya maksimum yang dapat dipancarkan atau diterima antena.[4]

\section{b. Impedansi Masukan}

Impedansi masukan didefinisikan sebagai impedansi yang diberikan oleh antena kepada rangkaian diluar, pada suatu titik acuan tertentu. Impedansi input akan dipengaruhi oleh antenaantena lain atau objek- objek yang dekat dengannya. Impedansi antena penting untuk pencapaian kondisi matching pada saat antena dihubungkan dengan sumber tegangan, sehingga semua sinyal yang dikirim ke antena akan terpancarkan.

\section{c. Voltage Standing Wave Rasio (VSWR)}

VSWR adalah perbandingan gelombang berdiri (standing wave) maksimum (|V|max) dengan minimum ( $|\mathrm{V}| \mathrm{min})$. Pada saluran transmisi ada dua komponen gelombang tegangan, yaitu tegangan yang dikirimkan $(\mathrm{VO}+)$ dan tegangan yang direfleksikan (VO-). Perbandingan antara tegangan yang direfleksikan dengan yang dikirimkan disebut sebagai koefisien refleksi tegangan $(\Gamma)$.

$$
\Gamma=\frac{W_{0}^{-}}{V_{0}{ }^{+}}=\frac{z_{L}-z_{0}}{z_{L}+z_{0}}
$$

Keterangan :

Vo- = Tegangan yang direfleksikan

$\mathrm{Vo}+=$ Tegangan yang dikirimkan

Dimana $Z L$ adalah impedansi beban (load) dan ZO adalah impedansi saluran lossless. Koefisien refleksi tegangan $(\Gamma)$ memiliki nilai kompleks, yang mempresentasikan besarnya magnitude dan fasa dari refleksi. Rumus untuk mencari nilai VSWR adalah:

$$
V S W R=\frac{1-|\Gamma|}{1-|\Gamma|}
$$

Besar nilai VSWR yang ideal adalah 1, yang berarti semua daya yang diradiasikan antena pemancar diterima oleh antena penerima (match). Semakin besar nilai VSWR menunjukkan daya yang dipantulkan juga semakin besar dan semakin tidak match.[4]

\section{d. Gain Antena}

Gain antena adalah perbandingan daya pancar suatu antena terhadap daya pancar antena referensi, atau pertambahan daya yang diradiasikan pada arah tertentu dari suatu antena dibandingkan dengan daya yang diradiasikan pada arah yang sama oleh suatu antenna referensi. Gain antena menentukan seberapa besar sebuah antena memfokuskan energy pancarnya atau bisa disebut dengan power gain.

Antena standar digunakan sebagai antenna penerima dengan daya terima misalkan sebesar Ps (watt). Selanjutnya antena standar di gantikan dengan antena yang akan di ukur power gain-nya. Misalkan daya yang diterima adalah sebesar Pt (watt) sehingga, gain dari antena yang diuji tersebut adalah:[4]

$$
G=10 \log \left(\frac{p t}{p_{s}}\right)(d B) .
$$

\section{e. Bandwidth Antena}

Bandwidth atau lebar pita frekuensi antenna adalah interval frekuensi dimana antena dapat beroperasi dengan kinerja yang baik. Bandwidth antenna dapat diukur berdasarkan hubungan antara SWR terhadap frekuensi atau menggunakan hubungan gain terhadap frekuensi sebagaimana pada gambar 12 . 
Elektron Jurnal IImiah Volume 11 Nomor 1 Juni 2019

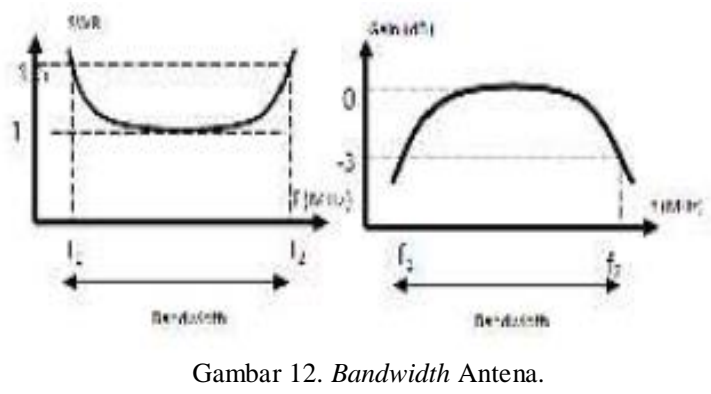

Karakteristik gain - frekuensi ini sangat penting karena antena yang memiliki gain yang tinggi akan memiliki bandwidth yang sempit.[4]

\section{f. Return Loss}

Return loss merupakan perbandingan antara amplitudo dari gelombang yang direfleksikan terhadap amplitudo gelombang yang dikirimkan. Return loss dapat terjadi karena adanya diskontinuitas di antara saluran transmisi dengan impedansi masukan beban (antena). Pada rangkaian gelombang mikro yang memiliki diskontinuitas (mismatched), besarnya return loss bervariasi tergantung dari frekuensi.

$$
\text { return loss }=20 \log _{10}|\Gamma|
$$

$$
\text { 11) }
$$

Nilai dari return loss yang baik adalah di bawah $-10 \mathrm{~dB}$, sehingga dapat dikatakan nilai gelombang yang direfleksikan tidak terlalu besar dibandingkan dengan gelombang yang dikirimkan atau dengan kata lain, saluran transmisi sudah matching. Nilai parameter ini menjadi salah satu acuan untuk melihat apakah antenna sudah dapat bekerja pada frekuensi yang diharapkan atau tidak.[4]

\section{g. Half Power Beam Width (HPBW)}

Beamwidth adalah lebar main lobe dari suatu antena, yang digunakan untuk mengukur direktivitas sebuah antena. Main lobe adalah daerah tegak lurus terhadap antena. Pada bagian tegak lurus (0o) menunjukkan arah pancaran atau penerimaan maksimum antena. Semakin kecil beamwidth maka semakin fokus sebuah antena memancarkan dayanya. Semakin besar beamwidth maka semakin besar juga fokus arah pancar dari antena. Rumus yang digunakan untuk mencari beamwidth:

Beamwidth = daya pancar maksimum $(-\mathrm{dB})-3 \mathrm{~dB}$

\section{h. Front to Back Ratio (FBR)}

Front to Back Ratio adalah perbandingan kuat pancaran pada arah depan dan belakang antena. Pada antena dengan pola radiasi dua arah (antena dipole) dimana kekuatan pancaran atau penerimaan arah depan dan arah belakang sama, maka FBR antena tersebut sama dengan 1.[4]

\subsubsection{Digital Video Broadcasting Terestrial (DVB-T)}

DVB-T lebih dikenal dengan siaran televise digital menjadi standar yang banyak dipakai di dunia dan juga tengah diadaptasi di Indonesia karena beberapa kelebihannya , terutama karena kehandalan DVB-T yang mampu mengirimkan sejumlah besar data pada kecepatan tinggi secara point to multipoint. Sistem DVB-T, merupakan sistem penyiaran langsung dari pemancar bumi (terrestrial) ke pemirsa di rumah. Fungsi pemancar bumi adalah untuk mentransmisikan data digital MPEG-2 yang telah dimodulasi menjadi gelombang VHF/UHF untuk dipancarkan menggunakan antena pemancar.[6]

\section{a. Kanal Frekuensi DVB-T}

Berdasarkan rekomendasi Tim Nasional Migrasi Penyiaran Analog ke Digital. Penerapan siaran televisi digital $D V B-T$ sebagai pengganti televisi analog pada pita $U H F$ dilakukan secara bertahap sampai suatu batas waktu cut-off televisi analog $U H F$ yang ditetapkan (2015 di kota besar dan 2020 secara nasional). Wilayah layanan televisi digital penerimaan tetap free-to-air $D V B-T$ adalah sama dengan wilayah layanan televisi analog $U H F$ sesuai

Keputusan Menteri Perhubungan No. 76 Tahun 2003. "Alokasi kanal frekuensi untuk layanan TV digital penerimaan tetap free-to-air $D V B-T$ di Indonesia adalah pada band IV dan VUHF" dengan lebar pita masing-masing kanal adalah $8 \mathrm{MHz}$.[6]

\section{b. Penerima DVB-T}

Pada unit penerima, dibutuhkan sistem penerima digital yang berupa set-top- box (STB) yang fungsinya menerima sinyal modulasi DVB-T dan mengolahnya sehingga siarannya dapat ditonton melalui televisi biasa. Perangkat STB ini bentuk dan fungsinya mirip seperti penerima satelit atau dekoder dan dihubungkan ke LNA terlebih dahulu sebelum ke antena agar dapat menerima sinyal dengan kualitas lebih baik. [6] 
Elektron Jurnal IImiah Volume 11 Nomor 1 Juni 2019

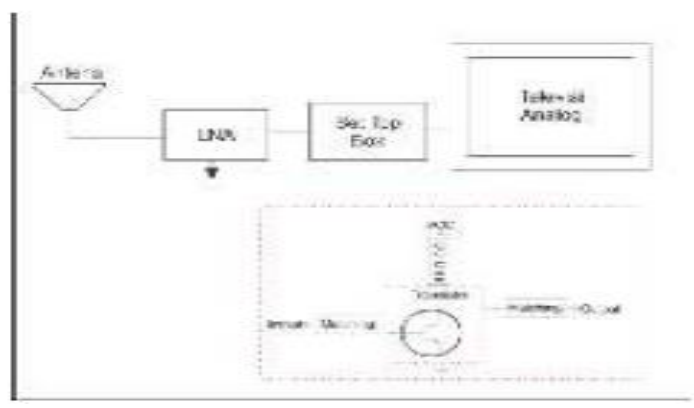

Gambar 13. Skema Penerima DVB-T

\section{HASIL DAN PEMBAHASAN}

3.1 Pengukuran Return loss dan VSWR Antena

Return loss merupakan perbandingan antara amplitudo dari gelombang yang direfleksikan terhadap amplitudo gelombang yang dikirimkan. Nilai dari return loss yang baik adalah di bawah $10 \mathrm{~dB}$, sehingga dapat dikatakan nilai gelombang yang direfleksikan tidak terlalu besar dibandingkan dengan gelombang yang dikirimkan atau dengan kata lain, saluran transmisi sudah matching. Nilai parameter ini menjadi salah satu acuan untuk melihat apakah antena sudah dapat bekerja pada frekuensi yang diharapkan atau tidak.

\section{A. Prosedur Pengukuran Return Loss dan VSWR Antena}

Pengukuran return loss dan VSWR antenna dilakukan di ruangan khusus yaitu Anechoic Chamber, dengan menggunakan Network Analyzer. Langkah Pengukuran :

1. Menghubungkan antena mikrostrip ke Network analyzer.

2. Mengatur frekuensi pada Network analyzer yaitu 1Mhz hingga $1 \mathrm{GHz}$.

3. Amati nilai return loss dan VSWR pada layar Network analyzer kemudian simpan hasil dalam bentuk file.

\section{B. Hasil Pengukuran Return Loss dan Gain Antena}

Setelah dilakukan pengukuran terhadap antenna maka didapatkan hasil return loss secara simulasi dan pengukuran yang ditunjukkan pada gambar. Dari return loss yang diperoleh, didapatkan bandwidth secara simulasi dan fabrikasi seperti pada gambar gambar 14

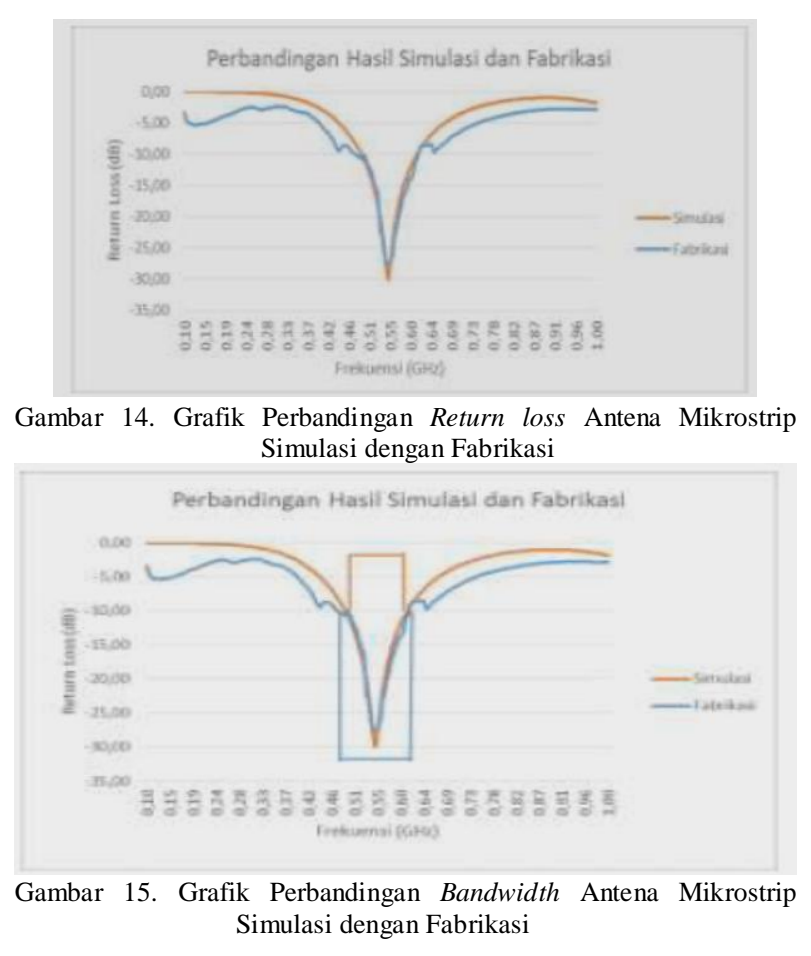

\section{3.. Hasil Pengukuran VSWR Antena}

Pengukuran VSWR berhubungan dengan koefisien refleksi dari antena tersebut. Berikut hasil VSWR secara simulasi dan pengukuran seperti yang ditunjukkan gambar 16 .

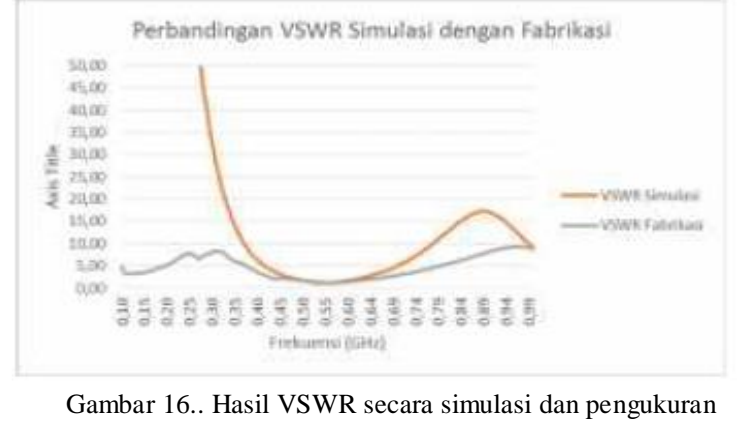

\subsection{Pengukuran Pola Radiasi Antena}

Pengukuran polaradiasi dilakukan untuk mengetahui arah pancaran gelombang dari antena yang telah dirancang. Pada pengukuran polaradiasi ini antenna mikrostrip ini akan di uji untuk polaradiasi secara horizontal dan vertikal.

A. Prosedur Pengukuran Pola Radiasi Antena

1. Memasang antena mikrostrip ke dalam mini chamber secara vertikal.

2. Mengatur format pola radiasi dalam bentuk 2D dan mengatur frekuensi $1 \mathrm{MHz}-1 \mathrm{Ghz}$ pada komputer penampil pola radiasi .

3. Menyimpan hasil pola radiasi dalam bentuk file. 


\section{B. Hasil Pengukuran Pola Radiasi Antena}

Setelah dilakukan pengukuran terhadap antenna maka diperoleh hasil dari pengukuran polaradiasi antenna Mikrostrip yang ditunjukkan pada gambar berikut:

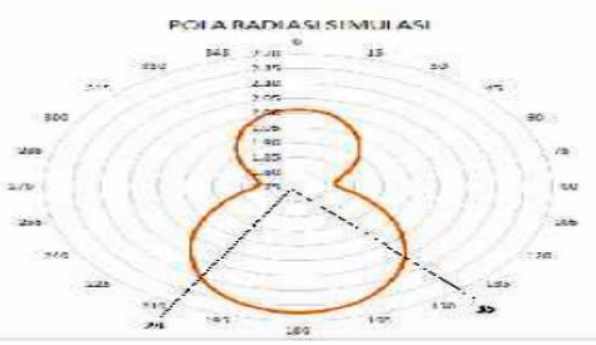

Gambar 17. Polaradiasi hasil Simulasi

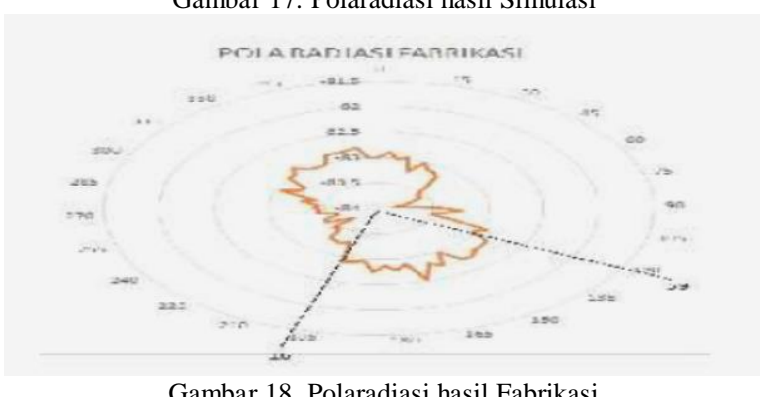

Gambar 18. Polaradiasi hasil Fabrikasi

\section{4..Pengukuran Front to Back Rasio (FBR)}

FBR merupakan perbandingan kuat pancaran pada arah depan dan arah belakangan sebuah antena. Berdasarkan tabel hasil simulasi dan pengukuran pola radiasi maka dapat dibandingkan hasil sudut $\left(0^{\circ}\right)$ dengan sudut $\left(180^{\circ}\right)$ dengan menggunakan teori sebagai berikut :

$\mathrm{FBR}=$ Arah pancar maksimum (sudut 0) - arah pancar minimum (sudut 180)

Tabel 3. Perbandingan Sudut $0^{\circ}$ Dengan Sudut $180^{\circ}$ Hasil Simulasi dan Fabrikasi Antena

\begin{tabular}{lcc}
\hline Arah Pancaran $\left(^{0}\right)$ & $\begin{array}{c}\text { Simulasi } \\
545 \mathrm{MHz}\end{array}$ & $\begin{array}{c}\text { Fabrikasi } \\
545 \mathrm{MHz}\end{array}$ \\
& & \\
\hline 0 & 2,01 & -83 \\
180 & 2,17 & $-82,87$ \\
Hasil & $-0,16$ & -0.13 \\
\hline
\end{tabular}

\subsection{Pengukuran Gain Antena}

Nilai gain yang didapatkan pada saat simulasi yaitu sebesar $5.5 \mathrm{dBi}$, nilai gain tersebut telah memenuhi kriteria untuk sebuah antena yang bekerja pada frekuensi wifi $545 \mathrm{MHz}$ adalah $\geq 3$ dBi. Sedangkan untuk pengukuran fabrikasi tidak dilakukan, karena parameter untuk antena referensi sebagai pembanding untuk mencari nilai gainnya tidak ada. Semakin besar gain yang didapatkan maka daya pancar antena tersebut akan semakin bagus. Berikut dibawah ini grafik gain hasil simulasi yang ditampilkan pada gambar 18

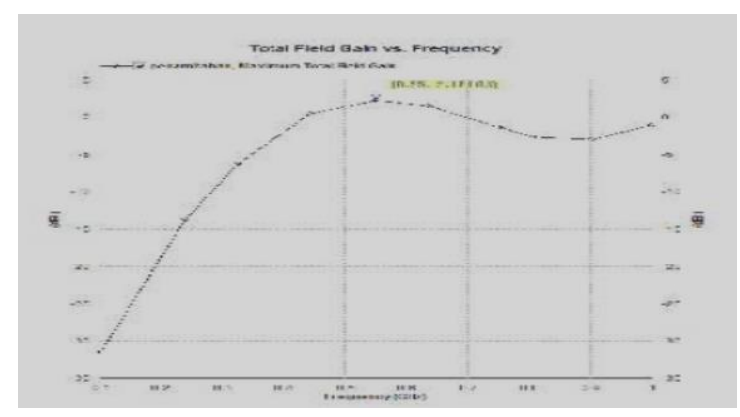

Gambar 18. Simulasi Gain Antena Mikrostrip Monopole Segi Empat

\subsection{Hasil dari Realisasi}

Realisasi merupakan suatu proses untuk menjadikan suatu rencana menjadi perwujuddan yang nyata. Untuk mendapat siaran digital antena di hubungkan dengan Set Top Box. Set Top Box berfungsi sebagai merubah sinyal analog menjadi sinyal digital. Seperti yang di tunjukan pada gambar 19. dan berikut hasil dari realisasi antena :

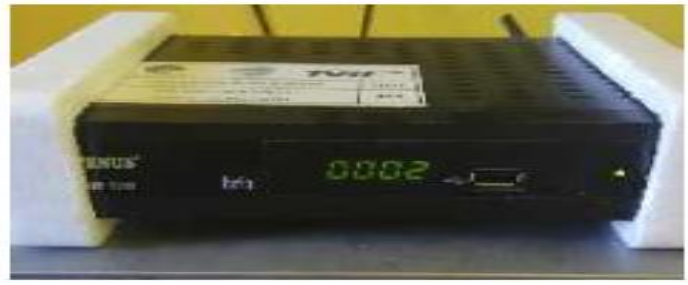

Gambar 19. Set Top Box

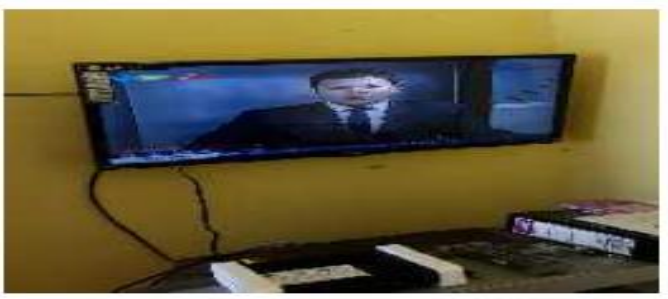

Gambar 20. Hasil Antena Di Pasang

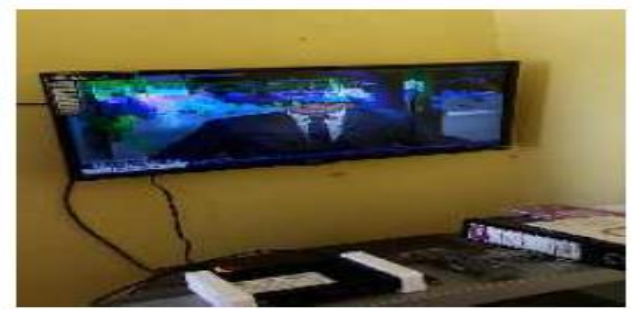

Gambar 21 Hasil Antena Tidak Di Pasang

Pada gambar 20. merupakan realisasi menggunakan antena dapat di lihat hasil yang di dapat bersih tidak gangguan dalam penerimaan sinyal. Sedang kan gambar 21 merupakan antena yang tidak di pasang, dapat di lihat hasil yang di 
dapat gambar tidak bergerak dan gambar pecahpecah.

\subsection{Analisa}

\section{a. Analisa Pengukuran Return Loss, Bandwidth Antena}

Pada hasil fabrikasi yang telah dilakukan seperti yang ditunjukkan pada gambar, diperoleh return loss dibawah $-10 \mathrm{~dB}$ yaitu dari frekuensi 545 MHz. Sedangkan hasil simulasi diperoleh return loss dibawah $-10 \mathrm{~dB}$ yaitu pada frekuensi $545 \mathrm{MHz}$.

Untuk dapat menentukan lebar nilai bandwidth dapat dilihat pada gambar diatas. Besarnya nilai bandwidth didapatkan dengan melihat antara frekuensi tertinggi dan frekuensi terendah pada daya terima $-10 \mathrm{~dB}$.

Pengukuran bandwidth bertujuan untuk mengetahui rentang frekuensi kerja dimana antena tersebut dapat bekerja secara maksimal dan besar cakupannya. Lebar bandwidth dapat dihitung dengan persamaan:

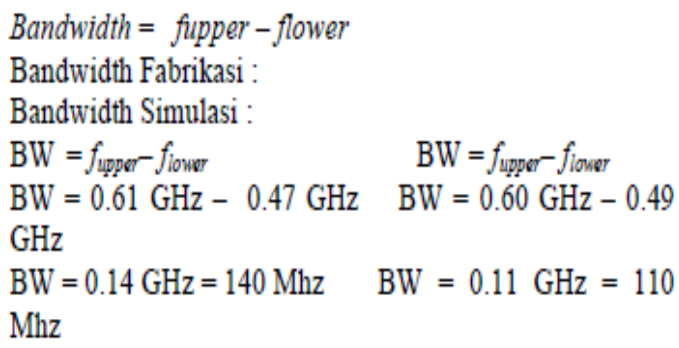

Tabel 4 Bandwidth Hasil Pengukuran dan Simulasi

\begin{tabular}{lcc}
\hline Nilai & Fabrikasi & Simulasi \\
\hline f upper & 610 & 600 \\
flower & 470 & 490 \\
Bandwidth $(\mathrm{MHz})$ & 140 & 110 \\
\hline
\end{tabular}

Tabel 4 merupakan hasil pengukuran bandwidth simulasi dan fabrikasi terlihat sedikit berbeda dikarenakan beberapa faktor seperti kostanta dielektrik yang tidak sesuai, serta faktor hambatan pada saat pengambilan data. Namun hasil pengukuran yang didapat telah maksimal dan sesuai dengan spesifikasi bandwidth aplikasi DVB-T.

\section{b. Analisa Hasil Pengukuran VSWR Antena}

Berarti hasil fabrikasi VSWR sudah bias dikatakan baik,karena level terima terbaik dari VSWR adalah mendekati 1. Semakin VSWR mendekati 1, maka semua daya yang diradiasikan antena pemancar diterima oleh antena menerima secara maksimal (match), tetapi apabila besar dari 1 maka daya yang dipantulkan semakin besar atau tidak macth. Perbedaan hasil simulasi dengan pengukuran dikarenakan beberapa faktor seperti kostanta dielektrik yang tidak tepat serta faktor hambatan pada saat pelarutan dan pengukuran.

\section{c. Analisa Hasil Pengukuran Polaradiasi dan HPBW Antena}

Dari pengukuran pola radiasi ini juga dapat diketahui nilai HPBW (Half Power Beam Width) antena yaitu dengan cara mencari sudut diantara dua titik pada main lobe dimana daya turun menjadi setengah daya turun, menjadi setengah daya pada level maksimum. Pada hasil simulasi diperoleh nilai HPBW sebesar $63^{\circ}$, sedangkan nilai HPBW hasil fabrikasi adalah sebesar $75^{\circ}$. Berdasarkan hasil pengukuran simulasi dan fabrikasi terlihat bahwa nilai HPBW hasil simulasi lebih baik dibandingkan dengan hasil fabrikasi, karena semakin sempit HPBW berarti semakin kuat pancaran suatu antena. Untuk perbandingan nilai HPBW hasil simulasi dengan hasil fabrikasi dapat dilihat pada gambar 17 dan gambar 18

\section{d. Analisa Pengukuran Front to Back Rasio(FBR)}

Dari pengukuran pola radiasi ini juga dapat diketahui nilai FBR (Front to Back Rasio) antena yaitu perbandingan kuat pancaran pada arah depan adan arah belakang sebuah antena. Pada pola radiasi antenna bidirectional, kuat pancaran di atas lebih besar dari pada yang di bawah atau sebaliknya.

\section{KESIMPULAN}

Berdasarkan perancangan, pengujian serta analisis yang telah dilakukan pada penelitian yang penulis buat maka penulis dapat mengambil beberapa kesimpulan diantaranya:

1. Antena bekerja secara maksimal pada frekuensi $545 \mathrm{MHz}$ dengan level terima sebesar $-25 \mathrm{~dB}$.

2. Antena memiliki bandwidth sebesar $140 \mathrm{MHz}$. Yang masih bisa dikatakan baik untuk digunakan.

3. Polaradiasi yang dihasilkan dari antena yaitu berbentuk bidirctional. Dengan HPBW antenna yaitu 75o dan FBR antena yaitu $-0.13 \mathrm{~dB}$.

4. VSWR antena yaitu 1.48 dan memiliki gain sebesar $5.5 \mathrm{~dB}$ pada hasil simulasi.

5. Ketidaksamaan parameter hasil simulasi dan hasil fabrikasi dapat terjadi karena adanya beberapa pengaruh yang salah satunya adalah 
nilai konstanta dielektrik papan PCB yang tidak diketahui.

6. Untuk melakukan realisasi, antena di hubungkan dengan set top box agar mendapat siaran digital

7. Pada saat antena di pasang gambar pada televisi bersih dan tidak ada ganguan. Sedangkan pada saat antena tidak di pasang maka gambar tidak bergerak dan gambar pecah-pecah.

\section{REFERENSI}

[1] Alaydrus, Mudrik. 2011. Antena Prinsip \& Aplikasi. Yogyakarta. Graha Ilmu.

[2] Febrianto, Wahyu. 2012. "Perancangan dan Pembuatan Antena Mikrostrip Pada Frekuensi 2,9 - 3,1 GHz". Penelitian. Padang : Politeknik Negeri Padang.

[3] Darmansyah, Rudi Putra. 2012. “Optimasi Antena Mikrostrip Patch Square Dengan Pencatuan Quarter- Wavelength Feed Pada Frekuensi 2.4 GHz Sebagai Penerima Sinyal Wireless Local Area Network (WLAN)". Penelitian. Padang : Politeknik Negeri Padang.

[4] Yulindon. Firdaus. 2008. Teori Dan Perencanaan Antena. Politeknik Negeri Padang.

[5] Puteri, Noviani Desriza. 2012. "Perancangan Dan Pembuatan Antena Mikrostrip Stacking Untuk Radio Altimeter". Penelitian. Padang : Politeknik Negeri Padang.

[6] Wicaksono, Hardian Cahya 2013. "Perancangan Dan Realisasi Antena Mikrostrip Log Periodik Pada Frekuensi 700 MHz untuk Aplikasi DVB-T 